\title{
Thermal comfort index in lactating cows in an adapted free-stall facility
}

João Marcos de Carvalho Vasconcelos ${ }^{1}$

Sindynara Ferreira ${ }^{2}$

Elisa de Souza Junqueira Rezende 3

José Luiz de Andrade Rezende Pereira ${ }^{4}$

\section{Abstract}

This study was conducted to investigate the thermoregulation of Holstein cattle in an adapted free-stall facility at IFSULDEMINAS, Campus Inconfidentes, by measuring thermal comfort indices. The experimental period was from the end of December 2012 to the start of January 2013, in a total of 16 days. 12 multiparous, lactating, black-and-white Holstein cows were used in a free-stall system. Rectal temperature, respiratory frequency, ambient temperature and relative humidity were recorded at 3:00 a.m., 7:00 a.m., 11:00 a.m., 3:00 p.m., 7:00 p.m. and 11:00 p.m. The results demonstrate that despite the temporal variations that occurred throughout the evaluation days, the confined animals maintained their body temperature in balance.

Keywords: Body temperature. Feedlot. Holstein cattle.

\section{Introduction}

The Brazilian territory is located on the tropic of Capricorn and under the tropical zone (FREITAS, 2014). In terms of climate, its main characteristic is the predominance of high temperatures as well as lack of a proper cold season (IBGE, 2006). In the face of those characteristic high temperatures, milk farmers resort to the use of animal-conditioning structures to minimize climatic adversities on cattle, such as heat stress.

According to Souza et al. (2004), the success of a milk production chain is associated with the adopted management. Accordingly, management is closely related to the adequacy of a project to the facilities. These should be set up so as to lessen climatic adversities inherent to the environment, providing greater comfort to animals and men, during all rearing phases. Various resources and stimuli must be observed for cattle to be in good welfare conditions, e.g., physical space, which will allow them to maintain their activities in a balanced social context; shelter, to protect them against weathering; and feed, including forages, water and supplements.

Some particularities define the degree of necessity and preference of each of these resources, depending on genetic and environmental traits. For instance, the need for shade depends on the ani-

1 Universidade Federal de São Carlos, mestrando.jmc_cbjr@yahoo.com.br.

2 Instituto Federal de Educação, Ciência e Tecnologia do Sul de Minas Gerais (IFSULDEMINAS), Campus Inconfidentes, professora doutora. sindynara.ferreira@ifsuldeminas.edu.br. Praça Tiradentes, 416. Centro. CEP 37576-000. Inconfidentes/MG. Brasil.

3 Universidade Estadual de Campinas. Faculdade de Engenharia Agrícola - FEAGRI, doutoranda. elisasjrezende@yahoo.com.br.

4 IFSULDEMINAS, professor doutor. joseluiz.pereira@ifsuldeminas.edu.br. 
mal's ability to adapt to the heat. Other factors that result in stress or trauma should be avoided, such as slippery floors, hot and stuffy restraint areas, high animal density, excessive noise, long periods without water or feed, equipment with ends that may cause trauma or other obstructions (PIRES; VERNEQUE; VILELA, 2001).

Animals live in dynamic balance with the environment and react to it individually. Their production is conditioned to influences of the environment, which does not remain constant over time. The vulnerability of animals to meteorological conditions when displaced to a different environment or when encountering changes in the same environment causes them to resort to physiological adaptation mechanisms in an attempt to maintain homeostasis (BACCARI JUNIOR, 2001). Heat stress causes alterations in homeostasis and in heat dissipation, increasing body temperature, which has a negative impact on animal performance.

Air temperature and humidity are considered the main climatic elements responsible for heat increment in the animal body temperature. If the animal is not able to dissipate the excess heat, its rectal temperature rises to values above normal physiological level and heat stress ensues, which is responsible for the low productivity in the tropics. Rectal temperature and respiratory frequency are physiological variables used to estimate the tolerance of animals to heat (BROWN BRANDL et al., 2003; BIANCA; KUNZ, 1978).

Therefore, the present study was conducted to analyze the thermoregulation of Holstein cattle from the Federal Institute of Education, Science and Technology of Southern Minas Gerais State IFSULDEMINAS - Inconfidentes Campus, confined in an adapted free-stall structure, by evaluating rectal temperature, respiratory frequency, ambient temperature and relative humidity.

\section{Material and methods}

The experiment was conducted at IFSULDEMINAS - Inconfidentes Campus, at the Educational Production Unit (UEP) - Dairy Cattle Farming. The campus is located in the municipality of Inconfidentes, southern Minas Gerais State, Brazil. According to the Köppen classification, the climate of the region is a subtropical type with dry winters and hot summers (Cwa) and two well-defined seasons: rainy (from October to March) and dry (from April to September). Average annual precipitation and temperature in the region are $1.800 \mathrm{~mm}$ and $19^{\circ} \mathrm{C}$, respectively (PEREIRA et al., 2011).

The experimental period consisted of 16 collection days between December 2012 and the beginning of January 2013. 12 multiparous, lactating, black-and-white Holstein cows were used in a free-stall system. It is important to stress that the free-stall system was adapted, since the calf nursery of the unit was in operation until the year 2007.

Animal management during the observations was standardized by defining daily feeding times (7:00 a.m., 10:00 a.m., 1:00 p.m., 3:00 p.m. and 6:00 p.m.), when a complete diet composed of roughage and concentrate (35 kg and $5 \mathrm{~kg}$, respectively) was provided; and 2 milking sessions (7:00 a.m. and 6:00 p.m.), whose yields were recorded daily.

Rectal temperature was measured with a Kruuse veterinary thermometer at 3:00 a.m., 7:00 a.m., 11:00 a.m., 3:00 p.m., 7:00 p.m. and 11:00 p.m. The animals were approached in a way that no stress would be caused. Accordingly, the thermometer was introduced directly into the animal's rectum for $1 \mathrm{~min}$ for stabilization and to obtain the temperature. The obtained values were compared to those found by Auad et al. (2010), as shown in Table 1. 
Table 1 - Rectal temperature of cattle for quantifying stress levels.

\begin{tabular}{ll}
\hline \multicolumn{1}{c}{ Rectal T $\left({ }^{\circ} \mathbf{C}\right)$} & \\
\hline 38.3 & No stress. \\
38.4 to 38.6 & Stress under control: appetite and reproduction normal. \\
39.1 & Early heat stress: lower appetite, but reproduction and production stable. \\
40.1 & $\begin{array}{l}\text { Marked stress: appetite decreases, production decreases, heat (estrus) symptoms almost } \\
\text { disappear. It is the onset of the problem. }\end{array}$ \\
40.9 & $\begin{array}{l}\text { Severe stress: great losses in production, intake decreases by 50\% and fertility may drop } \\
\text { to } 12 \% .\end{array}$ \\
\hline 41 & Deadly stress: cows expose their tongue and drool excessively; cannot drink water or eat.
\end{tabular}

Adapted from: Dairy Cattle Farming Manual (AUAD et al., 2010).

To measure respiratory frequency, the observers would record the number of respiratory movements performed by the animal within one minute, using a digital timer. Record times throughout the days were 3:00 a.m., 7:00 a.m., 11:00 a.m., 3:00 p.m., 7:00 p.m. and 11:00 p.m. The observed body area was the flank. The number of respiratory movements was compared to those described by Auad et al. (2010) (TABLE 2).

Table 2 - Respiratory frequency of cattle for quantifying stress levels.

\begin{tabular}{ll}
\hline \multicolumn{1}{c}{ Respiratory frequency } & \multicolumn{1}{c}{ Stress level } \\
\hline $23 \mathrm{mov} . / \mathrm{min}$. & No stress. \\
45 to $60 \mathrm{mov} / \mathrm{min}$. & Stress under control: appetite and reproduction normal. \\
$70 \mathrm{to} 75 \mathrm{mov} / \mathrm{min}$. & Early heat stress: lower appetite, but reproduction and production stable. \\
& $\begin{array}{l}\text { Marked stress: appetite decreases, production decreases, heat (estrus) } \\
\text { symptoms almost disappear. It is the onset of the problem. }\end{array}$ \\
& $\begin{array}{l}\text { Severe stress: great losses in production, intake decreases by } 50 \% \text { and fertility } \\
\text { may drop to } 12 \% .\end{array}$ \\
& $\begin{array}{l}\text { Deadly stress: cows expose their tongue and drool excessively; cannot drink } \\
\text { water or eat. }\end{array}$ \\
\hline
\end{tabular}

Adapted from: Dairy Cattle Farming Manual (AUAD et al., 2010).

Ambient temperature data were collected using a ThermoHygro instrument. Samples were collected at breast height, always in the middle of the evaluated environments (free stalls), at the following times: 3:00 a.m., 7:00 a.m., 11:00 a.m., 3:00 p.m., 7:00 p.m. and 11:00 p.m. Relative humidity was recorded by the same device, adopting the same procedure and collection times.

After tabulating the data, they were analyzed statistically according to the different evaluated times (3:00 a.m., 7:00 a.m., 11:00 a.m., 3:00 p.m., 7:00 p.m. and 11:00 p.m.) and periods (days). The evaluated parameters were analyzed by ANOVA and means were compared by the Scott-Knott test (1974) at the 5\% probability level, using SISVAR 4.3 software (FERREIRA, 2011) and applying correlation. 


\section{Results and discussion}

The present results for rectal temperature revealed significant differences between the animals (TABLE 3), with a variation range of $0.6^{\circ} \mathrm{C}$. Rectal temperature in dairy animals can vary with age, weight, breed, sex, nutritional value of the diet, lactation curve and reproduction cycle (SILVA, 2000). Adaptation to a given environment is related to structural, functional, or behavioral changes, which are aimed at survival, reproduction and production in extreme or adverse conditions (PORCIONATO et al., 2009).

Table 3 - Mean rectal temperature (in ${ }^{\circ} \mathrm{C}$ ) of animals during the evaluation period. IFSULDEMINAS - Inconfidentes Campus. Inconfidentes/MG, Brazil, 2014.

\begin{tabular}{lll}
\hline Day* & Rectal T $\left({ }^{\circ} \mathbf{C}\right)$ & \\
\hline 13 & 38.06 & $\mathrm{a}$ \\
11 & 38.10 & $\mathrm{a}$ \\
10 & 38.11 & $\mathrm{a}$ \\
7 & 38.14 & $\mathrm{a}$ \\
8 & 38.19 & $\mathrm{~b}$ \\
12 & 38.21 & $\mathrm{~b}$ \\
1 & 38.22 & $\mathrm{~b}$ \\
14 & 38.23 & $\mathrm{~b}$ \\
15 & 38.26 & $\mathrm{~b}$ \\
16 & 38.26 & $\mathrm{~b}$ \\
9 & 38.27 & $\mathrm{~b}$ \\
2 & 38.28 & $\mathrm{~b}$ \\
3 & 38.35 & $\mathrm{~b}$ \\
5 & 38.44 & $\mathrm{c}$ \\
4 & 38.49 & $\mathrm{c}$ \\
6 & 38.66 & $\mathrm{~d}$ \\
\hline Overall mean & 38.27 & \\
\hline CV (\%) & 1.73 & \\
\hline
\end{tabular}

*Means followed by a common letter in the column do not differ according to the Scott-Knott test (1974) at the $5 \%$ probability level.

Source: Elaborated by the authors (2015).

Based on the results, rectal temperature was higher on the first days of analysis. In addition to environmental factors such as high ambient temperature, the fact that higher rectal temperatures were recorded in those first days might have been due to the period of adaptation to the environment, since, in the beginning, the animal started to walk as soon as the evaluator would approach it. Auad et al. (2010) reported that rectal temperature values in dairy cattle between 38.4 and $38.6{ }^{\circ} \mathrm{C}$ indicate that the stress level is under control and appetite as well as reproduction are normal.

Only the sixth day was considered worrisome, since average rectal temperature was higher than normal. In order to maintain body temperature at thermoneutrality, the animal organism reduces its 
metabolic rate in an attempt to adjust to the environment and local climatic conditions (GONZÁLEZ; CAMPOS, 2003).

When the different times were evaluated, no statistically different rectal temperature was found in the animals (TABLE 4). This variable averaged $38.27^{\circ} \mathrm{C}$, indicating no stress. Lactating cows spend most of their time in the free stall, leaving the facility only at the milking times. In this case, it is essential to provide a comfortable environment to the animals, since lack of comfort may compromise production performance (BROUK et al., 2001).

According to Pires et al. (2001), lactating cows feed 10 to 12 times daily, with approximately $68 \%$ of those meals occurring between $06 \mathrm{hO0}$ and $18 \mathrm{~h} 00$. Though stabled and thus in an environment completely distinct from the natural environment, the daytime feeding pattern is similar to that observed when grazing, only that the total feeding time is lower. Under high temperature conditions, there is an increase in voluntary feed intake at night, indicating that there may be changes in feeding behavior as a way to lessen the effects of heat. Animals interrupt their feed consumption during the hotter times of the day, seeking a way to refresh themselves, or in an effort to reduce metabolic heat production.

Table 4 - Mean rectal temperature (in ${ }^{\circ} \mathrm{C}$ ) at the different evaluation times. IFSULDEMINAS - Inconfidentes Campus. Inconfidentes/MG, Brazil, 2014.

\begin{tabular}{ll}
\hline Time* & Rectal T $\left({ }^{\circ} \mathbf{C}\right)$ \\
\hline 7:00 a.m. & $37.93 \mathrm{a}$ \\
3:00 a.m. & $38.09 \mathrm{a}$ \\
11:00 a.m. & $38.20 \mathrm{a}$ \\
11:00 p.m. & $38.30 \mathrm{a}$ \\
3:00 p.m. & $38.42 \mathrm{a}$ \\
7:00 p.m. & $38.66 \mathrm{a}$ \\
\hline Overall mean & 38.27 \\
\hline CV (\%) & 1.73 \\
\hline
\end{tabular}

*Means followed by a common letter in the column do not differ according to the Scott-Knott test (1974) at the 5\% probability level.

Source: Elaborated by the authors (2015).

Though not statistically different, rectal temperature was lower at 7:00 a.m. compared to the other times, which is an expected finding, given the lower (or absent) insolation. These findings corroborate those published by Salviano et al. (2008), who evaluated the rectal temperature of cows between the morning (7:00 a.m.) and afternoon (3:00 p.m.) periods and found an increase of more than $0.5^{\circ} \mathrm{C}$ from morning to afternoon. In an attempt to dissipate the stressful climatic agents (temperature and humidity), the animal organism elevates its respiratory frequency, which can vary according to the ambience provided by the structure (AZEVEDO et al., 2005).

The highest respiratory frequency means (Table 5 ) in the evaluated animals coincided with the days with the hottest temperatures. 
Table 5 - Mean respiratory frequency (per minute) on the different days, in the evaluated animals. Inconfidentes Campus. Inconfidentes/MG, Brazil, 2014.

\begin{tabular}{ll}
\hline Da** & Respiratory frequency \\
\hline 12 & $38.50 \mathrm{a}$ \\
10 & $38.80 \mathrm{a}$ \\
13 & $39.01 \mathrm{a}$ \\
2 & $39.06 \mathrm{a}$ \\
7 & $39.39 \mathrm{a}$ \\
9 & $39.44 \mathrm{a}$ \\
14 & $39.50 \mathrm{a}$ \\
11 & $39.68 \mathrm{a}$ \\
8 & $40.12 \mathrm{a}$ \\
1 & $41.02 \mathrm{~b}$ \\
3 & $41.29 \mathrm{~b}$ \\
16 & $41.95 \mathrm{~b}$ \\
15 & $42.13 \mathrm{~b}$ \\
5 & $42.21 \mathrm{~b}$ \\
4 & $43.91 \quad \mathrm{c}$ \\
6 & $44.81 \quad \mathrm{c}$ \\
\hline Overall mean & 40.68 \\
\hline CV (\%) & 15.65 \\
\hline
\end{tabular}

*Means followed by a common letter in the column do not differ according to the Scott-Knott test (1974) at the 5\% probability level.

Source: Elaborated by the authors (2015).

According to Matarazzo (2004), increases in respiratory frequency in a short period of time characterize an efficient heat loss mechanism. However, when this mechanism starts to be required for prolonged periods, it may cause problems to animals, such as interferences with feed intake and rumination, production of additional endogenous heat due to muscular activity (panting) and diversion of energy from other metabolic processes. Based on the reports of Auad et al. (2010), the respiratory frequencies measured in each evaluated animal indicate that stress was under control.

Data analysis revealed a range of 6.31 between the mean numbers of respiratory movements per minute. Heat loss through the respiratory tract, as well as through the skin, implies a process of change of physiological state from liquid to vapor, which occurs with the air humidified in the upper respiratory tract, as with sweat. The energy expended by cows to eliminate heat from the body, especially through an increase in respiratory frequency, and also by the work of sweat glands to produce more sweat, is one of the factors that explain lower milk production under heat stress, since body energy is diverted from the productive process to the maintenance of physiological balance (BACCARI JUNIOR, 2001).

As shown in Table 6, the average number of respiratory movements per minute at 3:00 p.m, 7:00 p.m. and 11:00 p.m. was 41.73, which indicates thermal accumulation in the facility. According to Marques (2009), respiratory frequency is an indicator of heat stress, as it increases along with 
the ambient temperature in order to dissipate heat and maintain homeothermy, which the present findings corroborate.

Table 6 - Mean respiratory frequency (per minute) of the animals, evaluated at different times. IFSULDEMINAS - Inconfidentes Campus. Inconfidentes/MG, Brazil, 2014.

\begin{tabular}{ll}
\hline Time* $^{*}$ & Respiratory frequency \\
\hline 7:00 a.m. & $38.72 \mathrm{a}$ \\
11:00 a.m. & $39.52 \mathrm{~b}$ \\
3:00 a.m. & $40.60 \mathrm{c}$ \\
7:00 p.m. & $41.38 \mathrm{~d}$ \\
3:00 p.m. & $41.86 \mathrm{~d}$ \\
11:00 p.m. & $41.96 \mathrm{~d}$ \\
\hline Overall mean & $40.68 \mathrm{C}$ \\
\hline CV (\%) & 15.65 \\
\hline
\end{tabular}

*Means followed by a common letter in the column do not differ according to the Scott-Knott test (1974) at the 5\% probability level.

Source: Elaborated by the authors (2015).

Considering the results found by Almeida (2009), the average respiratory frequency of the animals in all treatments in the morning was lower than in the afternoon, because it is easier for the animal to dissipate heat at night and to be more thermally comfortable in the morning. However, respiratory frequency is the most sensitive indicator of thermal discomfort by the animal. In the afternoon period, respiratory frequency tends to increase according to how each animal manages to interact with its environment.

During the evaluation days, ambient temperature could be divided into two groups: the first comprised an intermediate and final evaluation date, when temperatures lower than $24{ }^{\circ} \mathrm{C}$ were observed, which are considered near the thermal comfort zone. In the second group, ambient temperatures higher than $24{ }^{\circ} \mathrm{C}$ were recorded, which, according to Brito et al. (2009), are critical for confined animals (TABLE 7). 
Table 7 - Mean ambient temperature (in ${ }^{\circ} \mathrm{C}$ ) on the different days. IFSULDEMINAS - Inconfidentes Campus. Inconfidentes/MG, Brazil, 2014.

\begin{tabular}{ll}
\hline Day* & $\mathbf{T}\left({ }^{\circ} \mathrm{C}\right)$ \\
\hline 9 & $22.82 \mathrm{a}$ \\
7 & $22.99 \mathrm{a}$ \\
13 & $23.15 \mathrm{a}$ \\
16 & $23.31 \mathrm{a}$ \\
14 & $23.61 \mathrm{a}$ \\
11 & $23.71 \mathrm{a}$ \\
10 & $23.72 \mathrm{a}$ \\
12 & $24.12 \mathrm{~b}$ \\
2 & $24.27 \mathrm{~b}$ \\
15 & $24.38 \mathrm{~b}$ \\
8 & $24.75 \mathrm{~b}$ \\
3 & $24.92 \mathrm{~b}$ \\
5 & $25.11 \mathrm{~b}$ \\
1 & $25.13 \mathrm{~b}$ \\
4 & $25.52 \mathrm{~b}$ \\
6 & $25.72 \mathrm{~b}$ \\
\hline Overall mean & 24.20 \\
\hline CV (\%) & 1.05 \\
\hline
\end{tabular}

*Means followed by a common letter in the column do not differ according to the Scott-Knott test (1974) at the 5\% probability level.

Source: Elaborated by the authors (2015).

The low milk yield in tropical regions is a result of the hot climate, which prevents adequate animal performance, since increasing ambient temperatures lead to a decrease in productivity (ANTUNES et al., 2009). According to Brito et al. (2009), the most adequate conditions for European cattle are an average monthly mean temperature below $20.0^{\circ} \mathrm{C}$. Temperatures between $24.0^{\circ} \mathrm{C}$ and $26.0^{\circ} \mathrm{C}$ reduce feed intake and production, and the thermal comfort zone lies between $1.0^{\circ} \mathrm{C}$ and $21.0^{\circ} \mathrm{C}$. For lactation cows, the temperature range between $7.0^{\circ} \mathrm{C}$ and $26.0^{\circ} \mathrm{C}$ is considered optimal; from $27.0^{\circ} \mathrm{C}$ to $34.0^{\circ} \mathrm{C}$, regular; and, above $35.0^{\circ} \mathrm{C}$, critical (MOTA, 2001). Therefore, high ambient temperatures will reduce the animal's ability to irradiate body heat, thereby reducing thermal balance, which will result in body weight loss and a decrease in milk production. The Brazilian dairy cattle sector is in a worrisome temperature range, where feed intake might decrease, thus requiring care and monitoring for the Holstein cattle breed in question.

No significant differences were found for mean ambient temperature between the evaluated times (TABLE 8). 
Table 8 - Mean ambient temperature (in ${ }^{\circ} \mathrm{C}$ ) at the different times. IFSULDEMINAS - Inconfidentes Campus. Inconfidentes/MG, Brazil, 2014.

\begin{tabular}{ll}
\hline Time & Temperature $\left({ }^{\circ} \mathbf{C}\right)$ \\
\hline 7:00 a.m. & $22.41 \mathrm{a}$ \\
3:00 a.m. & $22.71 \mathrm{a}$ \\
11:00 p.m. & $23.51 \mathrm{a}$ \\
7:00 p.m. & $24.69 \mathrm{a}$ \\
11:00 a.m. & $25.44 \mathrm{a}$ \\
3:00 p.m. & $26.45 \mathrm{a}$ \\
\hline Overall mean & 24.20 \\
\hline CV (\%) & 0.74 \\
\hline
\end{tabular}

*Means followed by a common letter in the column do not differ according to the Scott-Knott test (1974) at the 5\% probability level.

Source: Elaborated by the authors (2015).

Despite the lack of differences, a variation range of $4.04{ }^{\circ} \mathrm{C}$ was observed for ambient temperature, with 3:00 p.m. being the hottest hour. This is a worrisome finding, since, at this time, the cattle are within confinement, which may compromise animal body functions such as fertility and production (BRITO et al., 2009). The data obtained in the present study corroborate those reported by Matarazzo (2004), who found an increase in temperature from 9:00 a.m. to 5:00 p.m. in a free-stall system.

Significant differences were found for relative humidity, which was below $89.0 \%$ on seven non-consecutive days. On the other days, relative humidity rose to values above $90.0 \%$ (TABLE 9).

Table 9 - Mean air relative humidity (in percentage terms - \%) on all evaluation days. IFSULDEMINAS Inconfidentes Campus. Inconfidentes/MG, Brazil, 2014.

\begin{tabular}{ll}
\hline Day* & RH (\%) \\
\hline 8 & $76.44 \mathrm{a}$ \\
6 & $78.27 \mathrm{a}$ \\
1 & $82.88 \mathrm{a}$ \\
4 & $84.00 \mathrm{a}$ \\
5 & $84.38 \mathrm{a}$ \\
15 & $87.77 \mathrm{a}$ \\
7 & $88.77 \mathrm{a}$ \\
3 & $90.33 \mathrm{~b}$ \\
9 & $90.72 \mathrm{~b}$ \\
14 & $91.61 \mathrm{~b}$ \\
13 & $91.83 \mathrm{~b}$ \\
16 & $91.88 \mathrm{~b}$ \\
10 & $94.77 \mathrm{~b}$ \\
11 & $95.33 \mathrm{~b}$ \\
2 & $96.27 \mathrm{~b}$ \\
12 & $97.00 \mathrm{~b}$ \\
\hline
\end{tabular}




\begin{tabular}{lc}
\hline Overall mean & 88.89 \\
\hline $\mathrm{CV}(\%)$ & 0.31 \\
\hline
\end{tabular}

* Means followed by a common letter in the column do not differ according to the Scott-Knott test (1974) at the 5\% probability level.

Source: Elaborated by the authors (2015).

Humidity over $90 \%$ was represented by the occurrence of rain in the experimental area. In the evaluation of relative humidity across the times of the day, no significant difference was detected (TABLE 10). Brito et al. (2009) reported that the most adequate relative humidity condition for European cattle (Bos taurus) is $50 \%$ to $80 \%$. When certain limits are exceeded (heat stress levels), their health and productive and reproductive performance are compromised.

Table 10 - Mean relative humidity (in percentage terms - \%) at the different times. IFSULDEMINAS Inconfidentes Campus. Inconfidentes/MG, Brazil, 2014.

\begin{tabular}{ll}
\hline Time* & RH (\%) \\
\hline 3:00 p.m. & $84.72 \mathrm{a}$ \\
7:00 p.m. & $88.18 \mathrm{a}$ \\
11:00 a.m. & $88.22 \mathrm{a}$ \\
11:00 p.m. & $89.47 \mathrm{a}$ \\
7:00 a.m. & $91.25 \mathrm{a}$ \\
3:00 a.m. & $91.50 \mathrm{a}$ \\
\hline Overall mean & 88.89 \\
\hline CV (\%) & 0.33 \\
\hline
\end{tabular}

*Means followed by a common letter in the column do not differ according to the Scott-Knott test (1974) at the 5\% probability level.

Source: Elaborated by the authors (2015).

A comparison of relative humidity to ambient temperature between the different times showed that ambient temperature dropped as humidity in the environment increased. Pires and Campos (2003) found higher relative humidity indices in the morning and night periods and lower values in the afternoon periods, which the present findings corroborate.

Rectal temperature was positively correlated with respiratory frequency (0.29) and ambient temperature (0.30), which means the animals' body temperature will increase if those variables increase. Rectal temperature was negatively correlated $(-0.22)$ with relative humidity; i.e., as relative humidity increases, body temperature decreases, promoting thermal comfort to the animal. Respiratory frequency was positively correlated with ambient temperature (0.29), meaning the animal expends more energy to maintain homeostatic balance; but negatively $(0.22)$ with relative humidity. Ambient temperature was negatively correlated with relative humidity $(-0.38)$, indicating that this variable decreased as temperature rose. 


\section{Conclusion}

The adapted free stall at the Dairy Farming Cattle Section of IFSULDEMINAS - Inconfidentes Campus is located in an area where confined animals have their body temperature in balance, despite variations in the temperature and relative humidity inside the facility.

\section{Acknowledgments}

To the "Federal Institute of Education, Science and Technology of South of Minas Gerais - IFSULDEMINAS" for the financial support granted.

\section{Índices de conforto térmico de vacas lactantes em instalação free stall adaptada}

\section{Resumo}

Com o objetivo de avaliar a termorregulação do gado holandês em instalação adaptada de sistema free stall do IFSULDEMINAS, Campus Inconfidentes, o presente trabalho foi realizado avaliando os índices de conforto térmico. O período experimental foi de 16 dias, entre dezembro/2012 e início de janeiro/2013. Foram utilizadas 12 vacas da raça holandês preta e branca, multíparas e em lactação. Os animais se encontravam confinados em sistema free stall. Foram avaliadas temperatura retal, frequência respiratória, temperatura ambiente e umidade relativa nos seguintes horários 3h, 7h, 11h, $15 \mathrm{~h}, 19 \mathrm{~h}$ e $23 \mathrm{~h}$. Os resultados encontrados demonstram que, apesar das variações temporais ao decorrer dos dias avaliados, os animais nele confinados tiveram a temperatura corporal em equilíbrio. Palavras-chave: Confinamento. Gado holandês. Temperatura corporal.

\section{References}

ALMEIDA, G.L.P. Climatização na pré-ordenha de vacas da raça Girolando e seus efeitos na produção e qualidade do leite e no comportamento animal. 2009. 135 f. il. Dissertação (Mestrado). Universidade Federal Rural de Pernambuco. Pernambuco/PE.

ANTUNES, M.M., PAZINATO, P.G., PEREIRA, R.A., SCHNEIDER, A., BIANCHI, I., CORRÊA, M.N. Efeitos do estresse calórico sobre a produção e reprodução do gado leiteiro. Núcleo de Pesquisa, Ensino e Extensão em Pecuária. Universidade Federal de Pelotas. Pelotas. 2009. 5. Disponível em: <http://www.grupocultivar.com.br/arquivos/estresse.pdf>. Acesso em: 28 mar. 2015.

AUAD, A. M.; BRIGHENTI, A. M.; CARNEIRO, A. V.; RIBEIRO, A. C. de C. L.; CARVALHO, A. da C.; FREITAS, A. F. de; CARVALHO, B. C. de; ALENCAR, C. A. B. de; GOMIDE, C. A. de M.; MARTINS, C. E.; CASTRO, C. R. T. de; PACIULLO, D. S. C.; NASCIMENTO JUNIOR, E. R. do; SOUZA SOBRINHO, F. de; DERESZ, F.; LOPES, F. C. F.; SOUZA, G. N. de; WERNERSBACH FILHO, H. L.; OLIVEIRA, J. 
S. e; CARNEIRO, J. da C.; VIANA, J. H. M.; FURLONG, J.; MENDONCA, L. C.; STOCK, L. A.; CAMARGO, L. S. de A.; MULLER, M. D.; OTENIO, M. H.; PEREIRA, M. C.; MACHADO, M. A.; GAMA, M. A. S. da; JUNQUEIRA, M. M.; SILVA, M. V. G. B.; PIRES, M. de F. A.; PEIXOTO, M. G. C. D.; GUIMARAES, M. F. M.; TORRES, R. de A.; TEIXEIRA, S. R.; OLIVEIRA, V. M. de; ROCHA, W. S. D. da Manual de bovinocultura de leite. Brasília: LK Editora; Belo Horizonte: SENAR-AR/MG; Juiz de Fora: Embrapa Gado de Leite, 2010. 607 p. il.

AZEVEdO, M., PIRES, M.F.Á., SATURNINO, H.M., LANA, Â.M.Q. SAMPAIO, I.B.M., MONTEIRO, J.B.N., MORATO, L.E.M. Estimativa de níveis críticos superiores do índice de temperatura e umidade para vacas leiteiras 1/2, 3/4 e 7/8 holandês-zebu em lactação. Revista Brasileira de Zootecnia, v. 34, n.6, p.2000-2008, 2005.

BACCARI JUNIOR, F. Manejo ambiental da vaca leiteira em climas quentes. Londrina: Editora da Universidade Estadual de Londrina, 2001, 142 p.

BIANCA, W., KUNZ, P. Physiological reactions of three breeds of goats to cold, heat an hight altitude. Livestock Production Science, Amsterdam, v.5, n.1, p.57-69, 1978.

BRITO, A.S., NOBRE, F.V., FONSECA, J.R.R. Bovinocultura de leite: informações técnicas e de gestão. Natal: SEBRAE/RN, 2009. 320 p. il. Disponível em: <http://www.bibliotecas.sebrae.com. br/chronus/ARQUIVOS_CHRONUS/bds/bds.nsf/59F7F0013C0E7280832576EB00692AFE/\$File/ NT00043CA6.pdf>. Acesso em: 28 mar. 2015.

BROUK, M.J., SMITH, J.F., HARNER III, J.P. Effectiveness of fan and feedline sprinklers in cooling dairy cattle housed in 2-or 4-row freestall buildings. In: International livestock Environmet Symposium, 6., Louisville, 2001. Proceedings. Louisville: ASAE, 2001.

BROWN-BRANDL, T.M., NIENABER, J.A., EIGENBERG, R.A., HAHN, G.L., FREETLY, H C. Thermoregulatory responses of feeder cattle. Journal of Thermal Biology, 2003. v.28, n. 2, p.149-157.

FERREIRA, D.F. Sisvar: a computer statistical analysis system. Ciência e Agrotecnologia, 2011. v. 35, n. 6, p. 1039-1042.

FREITAS, E. Zonas térmicas da Terra. 2014. Disponível em: <http://www.brasilescola.com/geografia/zonas-termicas-terra.htm >. Acesso em: 28 mar. 2015.

GONZÁLEZ, F.H.D, CAMPOS, R. Indicadores metabólico-nutricionais do leite. 2003. In: González, F.H.D., Campos, R. (eds.): Anais do I Simpósio de Patologia Clínica Veterinária da Região Sul do Brasil. Porto Alegre: Gráfica da Universidade Federal do Rio Grande do Sul. p.31-47.

IBGE - Instituto Brasileiro de Geografia e Estatística. Regiões tropicais ou zona tropical. 2006. Disponível em: <http://www.clickescolar.com.br/regioes-tropicais-ou-zona-tropical.htm>. Acesso em: 28 mar. 2015.

MARQUES, J.A. Estresse e a produção animal. Manual para a economia do produtor. IAPAR/EMATER-PR. 2009, p. 23. 
MATARAZZO, S.V. Eficiência do sistema de resfriamento adiabático evaporativo em confinamento do tipo free-stall para vacas em lactação. 2004. 143p. Tese (Doutorado). Escola Superior de Agricultura Luiz de Queiroz. Piracicaba/SP. Disponível em: < http://www.teses.usp.br/teses/disponiveis/11/11131/ tde-29042005-162015/pt-br.php>. Acesso em: 28 mar. 2015.

MOTA, F.S. Climatologia zootécnica. Pelotas: Edição do autor. 2001. 104p.

PEREIRA, M.W.M., BALIEIRO, K.R.C., PINTO, L.V.A. Avaliação da produtividade e adaptabilidade de acessos de amendoim forrageiro para potencial formação/consorciação de pastagens mais sustentáveis no sul de Minas Gerais. Revista Agrogeoambiental, 2011. v.3, n. 2, p. 37-45.

PIRES, M.F.A., CAMPOS, A.T. Relação dos dados climáticos com o desempenho animal. In: RESENDE, H., CAMPOS, A.T., PIRES, M.F.A. (Org). Dados climáticos e sua utilização na atividade leiteira. $1^{\text {a }}$ Edição. Juiz de Fora: CNPGL, 2003. v.1, 250 p.

PIRES, M.F.A., VERNEQUE, R.S., VILELA, D. Ambiente e comportamento na produção de leite. Informe Agropecuário, Belo Horizonte, v. 22, n. 211, p. 11-21, 2001.

PIRES, M.F.A.; VILELA, D.; ALVIM, M.J. Comportamento alimentar de vacas holandesas em sistemas de pastagens ou em confinamento. Juiz de Fora: Embrapa Gado de Leite, 2001. 2p. (Boletim Técnico 2).

PORCIONATO, M.A.F., FERNANDES, A. M., NETTO, A.S., SANTOS, M.V. Influência do estresse calórico na produção e qualidade do leite. Revista Acadêmica, Ciência Agrária Ambiental. Curitiba, v. 7 , n. 4. p. 483-490, 2009.

SALVIANO, L.M.C., VILLAÇA, C.L.P.B., VILAS BOAS, C.V.S., TAVARES, S.L.S. Parâmetros fisiológicos de um rebanho de bovinos da raça holandesa criado no semiárido brasileiro. In: $35^{\circ}$ Congresso Brasileiro de Medicina Veterinária, 2008.

SCOTT, A.; KNOTT, M. Cluster-analysis method for grouping means in analysis of variance. Biometrics, Washington D.C., v. 30, n.3, p.507-512, 1974.

SILVA, G.R. Introdução à bioclimatologia animal. São Paulo: FAPESP/Nobel, 2000. 286p.

SOUZA, C.F., et al. Instalações para gado de leite. 2004. Universidade Federal de Viçosa. Disponível em: <http://www.ufv.br/dea/ambiagro/arquivos/GadoLeiteOutubro-2004.pdf>. Acesso em: 28 mar. 2015.

Received: August 9, 2018

Accepted: February 4, 2019 